\title{
Excretion of Hypusine by Children and by Patients with Familial Hyperlysinemia
}

\author{
N. C. Woody ${ }^{[7]}$ and M. B. Pupene \\ Department of Pediatrics, Tulane University School of Medicine, and the Charity Hospital of Louisiana, New Orleans, Louisiana, USA
}

\section{Extract}

Three children with familial hyperlysinemia were found to excrete, respectively, 1,934 $\mathrm{nmol} / 24 \mathrm{hr}, 730 \mathrm{nmol} / 24 \mathrm{hr}$, and $1,121 \mathrm{nmol} / 24 \mathrm{hr}$ hypusine and $16.1 \mathrm{mmol} / 24 \mathrm{hr}$, $7.0 \mathrm{mmol} / 24 \mathrm{hr}$, and $16.6 \mathrm{mmol} / 24 \mathrm{hr}$ lysine. Ten juvenile control subjects excreted $35-253 \mathrm{nmol} / 24 \mathrm{hr}($ mean $156 \mathrm{nmol} / 24 \mathrm{hr}$ ) hypusine and $0.2-1.5 \mathrm{mmol} / 24 \mathrm{hr}$ (mean $0.7 \mathrm{mmol} / 24 \mathrm{hr}$ ) lysine. Three infant control subjects were found to excrete 156 $\mathrm{nmol} / 24 \mathrm{hr}, 60 \mathrm{nmol} / 24 \mathrm{hr}$, and $77 \mathrm{nmol} / 24 \mathrm{hr}$ hypusine. Serum levels of hypusine for subjects with hyperlysinemia were normal (less than $20 \mathrm{nmol} / 100 \mathrm{ml}$ ).

\section{Speculation}

Patients with familial hyperlysinemia excrete both hypusine and lysine at levels $7-10$ times higher than those observed for control subjects, while serum levels of hypusine in patients with hyperlysinemia are not elevated. These findings suggest that hypusine may be an endometabolite of lysine and not further metabolized or utilized.

\section{Introduction}

In 1971, Shiba et al. [2] reported isolation from bovine brain of a new basic amino acid which they named hypusine. They deduced its chemical structure, and showed it to be composed of two moieties: hydroxyputrescine and lysine. A few months later, the same group [1] reported that hypusine was also to be found in rat and rabbit brain and in rat liver, kidney, muscle, and blood. They also demonstrated hypusine in human urine and blood.

Herein, we report and compare excretion of hypusine by normal children and by children with familial hyperlysinemia.

\section{Materials and Methods}

Accurate 24-hr urine samples were collected under ice, stored at $4^{\circ}$, and processed within $48 \mathrm{hr}$ after collection. Using an aliquot of the 24-hr sample containing $20 \mathrm{mg}$ creatinine, the basic aliphatic amino acids were separated from the urine by the method outlined by
Nakajima et al. [1]. Serum from the subjects with hyperlysinemia was deproteinated with 10 volumes of $6 \%$ trichloroacetic acid [1] and similarly treated. Chromatography was carried out on the $22-\mathrm{cm}$ column of an automatic amino acid analyzer [5] using a standard resin [6] with $0.38 \mathrm{M}$ sodium citrate buffer, $\mathrm{pH} 4.25$, which contained $0.57 \mathrm{M} \mathrm{NaCl}$. Buffer flow rate was 50 $\mathrm{ml} / \mathrm{hr}$ and column temperature was $62.5^{\circ}$. Hypusine was eluted at $175 \mathrm{ml}$ as a clearly defined peak.

Authentic hypusine [3] was used as a standard for calculation of results and to confirm the identity of the peak at $175 \mathrm{ml}$. Addition of authentic hypusine to the urine extract on the column led to augmentation of the peak. Further confirmation of the identity of hypusine in urine came from two-dimensional paper chromatographic separation of the urine extracts on Whatman no. 1 paper, 10 by 10 inch, using 1-butanolacetic acid-water $(12 / 3 / 5, \mathrm{v} / \mathrm{v} / \mathrm{v})$ as the first solvent and phenol-ammonia $(200 / 1, v / v)$ as the second [3]. The spot identified as hypusine was reinforced when authentic hypusine was added. 
Table 1. Excretion of hypusine and lysine by hyperlysinemia and control subjects 1

\begin{tabular}{lrrrrr}
\hline \multicolumn{1}{c}{ Patients } & Age, yr & Race & Sex & $\begin{array}{c}\text { Hypusine, } \\
\text { nmol/24 } \\
\text { hr }\end{array}$ & $\begin{array}{c}\text { Lysine, } \\
\text { mmol/24 } \\
\text { hr }\end{array}$ \\
\hline $\begin{array}{l}\text { Hyperlysinemia subjects } \\
1\end{array}$ & $125 / 12$ & $\mathrm{C}$ & $\mathrm{F}$ & 1,934 & 16.1 \\
2 & $95 / 12$ & $\mathrm{C}$ & $\mathrm{M}$ & 730 & 7.0 \\
3 & $78 / 12$ & $\mathrm{C}$ & $\mathrm{F}$ & 1,121 & 16.6 \\
Juvenile control subjects & & & & & \\
1 & $59 / 12$ & $\mathrm{~N}$ & $\mathrm{M}$ & 134 & 0.2 \\
2 & $95 / 12$ & $\mathrm{~N}$ & $\mathrm{~F}$ & 39 & 0.7 \\
3 & $98 / 12$ & $\mathrm{~N}$ & $\mathrm{~F}$ & 37 & 0.2 \\
4 & $103 / 12$ & $\mathrm{~N}$ & $\mathrm{M}$ & 106 & 1.1 \\
5 & $105 / 12$ & $\mathrm{~N}$ & $\mathrm{~F}$ & 156 & 0.5 \\
6 & $106 / 12$ & $\mathrm{C}$ & $\mathrm{M}$ & 193 & 1.4 \\
7 & $101 / 12$ & $\mathrm{~N}$ & $\mathrm{M}$ & 171 & 0.2 \\
8 & $126 / 12$ & $\mathrm{C}$ & $\mathrm{F}$ & 271 & 0.4 \\
9 & $139 / 12$ & $\mathrm{~N}$ & $\mathrm{~F}$ & 198 & 1.5 \\
10 & $131 / 12$ & $\mathrm{C}$ & $\mathrm{M}$ & 253 & 0.8 \\
Infant control subjects & & & & & \\
1 & $9 / 12$ & $\mathrm{~N}$ & $\mathrm{M}$ & 156 & 2 \\
2 & $13 / 12$ & $\mathrm{~N}$ & $\mathrm{M}$ & 60 & 2 \\
3 & $13 / 12$ & $\mathrm{~N}$ & $\mathrm{M}$ & 77 & 2 \\
\hline
\end{tabular}

${ }^{1} \mathrm{~N}$ : Negro; G: Caucasian; F: female; $\mathrm{M}$ : male.

2 Not measured.

\section{Results}

Urine samples from 3 patients with familial hyperlysinemia, 10 juveniles, and 3 infants were analyzed for hypusine and lysine; results are shown in Table $\mathrm{x}$. When hypusine and lysine excretion are compared for the 10 juvenile controls, although the numbers studied are small, no obvious race or sex differences are seen and values are similar to those reported for Japanese children [1]. Hypusine excretion is 7-10 times higher in the patients with familial hyperlysinemia than in normal infants and children. It roughly parallels levels of lysine excretion by the two groups, which is $10-20$ times greater in the patients with hyperlysinemia than in control children.

With $10 \mathrm{ml}$ hyperlysinemic serum, we were not able to demonstrate hypusine. Because the method permits detection of $2 \mathrm{nmol} / \mathrm{sample}$, this funding indicates that serum hypusine levels for patients with hyperlysinemia were less than $20 \mathrm{nmol} / 100 \mathrm{ml}$, the value reported for normal human serum by Nakajima et al. [1].

\section{Discussion}

Diets for both normal subjects and patients with hyperlysinemia were not restricted as to lysine content. Hypusine content has thus far been reported only for certain mammalian tissues $[1,2]$, where the largest amounts have been found in brain, liver, and kidney. The remarkable variance of levels of hypusine in urine between subjects with hyperlysinemia and normal subjects seems hardly likely to be the result of dietary differences.

No plausible route for the biosynthesis of hypusine was suggested by the experiments of Shiba et al. [2]. Nakajima and associates [1] indicated that they had not studied hypusine biosynthesis but felt that "Iysine is quite possibly a precursor." The increased hypusine excretion observed for these patients with hyperlysinemia would seem to support this possibility. The normal serum levels and elevated levels of hypusine in urine found for patients with hyperlysinemia also supports another impression of Nakajima et al. [1]: that renal tubular reabsorption of hypusine does not occur and that hypusine is not further metabolized or utilized in man.

\section{Summary}

Three children with familial hyperlysinemia excreted hypusine at levels 7-10 times higher and lysine at levels 10-20 times higher than normal children. Serum hypusine levels for the patients with hyperlysinemia were not elevated. These findings support the hypothesis of others [1,2] that hypusine is an endometabolite of lysine and not further metabolized or utilized in man.

\section{References and Notes}

1. Nakajma, T., Matsubayashi, T., Kakimoto, Y., and Sano, I.: Distribution of hypusine, $\mathrm{N}^{\mathrm{G}}$-(4-amino-2-hydroxybutyl)-2, 6 diaminohexanoic acid, in mammalian organs. Biochim. Biophys. Acta, 252: 92 (1971).

2. Shiba, T., Mrzote, H., Kaneka, T., Nakajima, T., Kakimoto, Y., AND SANo, I.: Hypusine, a new amino acid occurring in bovine brain: Isolation and structural determination. Biochim. Biophys. Acta, 244: 523 (1971).

3. Surre, I.: Chromatographic and Electrophoretic Technics, p. 84 (Interscience Publishers, Inc., New York, 1960).

4. Kindly supplied by Dr. G. R. Stark, Stanford University School of Medicine, Palo Alto, California, and Dr. T. Shiba, Osaka University, Toyonaka, Japan.

5. Automatic amino acid analyzer, model 120-C, Beckman Instruments, Inc., Spinco Division, Palo Alto, Calif.

6. Aminex A-5, Bio-Rad Laboratories, Richmond, Calif.

7. Requests for reprints should be addressed to: N. C. Woody, M.D., Department of Pediatrics, Tulane University School of Medicine, 1430 'Tulane Ave., New Orleans, La., 70112 (USA).

8. Accepted for publication August 6, 1973. 